\title{
Policy Forum: Macroeconomic Policies and the Business Cycle: Evidence and Recommendations
}

\section{Introduction}

\section{Efrem Castelnuovo*}

This issue of the Policy Forum focuses on a theme that has become dominant in policymakers agenda since the global financial crisis: The role of monetary and fiscal policies play in stimulating consumption, supporting the business cycle, stabilizing inflation expectations, and influencing consumer and business confidence.

A lot of questions regarding the impact of fiscal policy were asked and debated in the context of the fifth edition of the Melbourne Institute Macroeconomic Policy Meetings, which took place on October 10-11, 2019. The goal of the event was to provide a forum for academics and policymakers to meet and talk about the state of macroeconomic policies and the challenges policymakers face in a context characterized by very low interest rates and concerns regarding debt sustainability. The Meeting featured eleven high quality scientific papers as well as a panel discussion facilitated by Warwick McKibbin (Crawford School of Public Policy at the Australian National University), with panelists: Ian Harper (Dean, Melbourne Business School, University of Melbourne, and board member of the Reserve Bank of Australia), Meghan Quinn (Deputy Secretary, Macroeconomic Group, Australian Treasury), and Jenny Wilkinson (Parliamentary Budget Officer, Parliament of Australia). Enrique Mendoza (University of Pennsylvania) and Fabio Canova (Norwegian Business School, CAMP and CEPR) offered keynote speeches on financial crises and sudden stops (the former speaker) and model misspecifications (the latter). The workshop, organized by Bruce Preston and myself, and sponsored by the Reserve Bank of Australia, Reserve Bank of New Zealand, the Australian Treasury, and the Department of Economics of the University of Melbourne, proved once again to be an excellent occasion for interactions between academics and policymakers on hot macroeconomic issues affecting Australia and countries around the world.

This policy forum contains three papers. Bruce Preston (University of Melbourne) opens the forum with "The Case for Reform of the RBA's Policy and Communication Strategy".

This is the author manuscript accepted for publication and undergone full peer review but has not been through the copyediting, typesetting, pagination and proofreading process, which may lead to differences between this version and the Version of Record. Please cite this article as doi: 10.1111/1467-8462.12363.

This article is protected by copyright. All rights reserved. 
Putting several recent policy statements under the microscope, and analyzing the way in which policy goals are stated, this excellent piece convincingly argues that Australian monetary policymakers have a too easy life in interpreting the macroeconomic outcomes of the last decade or so as a success. This because of the lack of precision in the definition of such goals, which is often reflected in loose statements by RBA's officials. Bruce then moves to the formulation of concrete proposals (e.g., the shift from inflation targeting to price-level targeting) in an attempt to stimulate a much needed constructive debate on the reforms that the RBA should implement to face the uncertain evolution of the Australian macroeconomy.

Business cycle stabilization requires an understanding of the drivers of real activity. One of the most important component of aggregate output in industrialized countries is aggregate consumption. What do we know about its determinants? In particular, how relevant is the role played by wealth for consumption decisions? In "Wealth and Consumption", Diego May, Gabriela Nodari and Daniel Rees (all Reserve Bank of Australia, with the last author currently visiting the Bank for International Settlements in Basel, Switzerland) investigate households' consumption response to changes in wealth in Australia. Their investigation identifies a positive and stable relationship between these two aggregates. Changes in spending on motor vehicles and durable goods are found to be particularly relevant for understanding the evolution of consumption. Interestingly, household wealth if found to have supported household spending between 2013 and 2017, a period characterized by weak disposable income. Interestingly, they point out that a decline in household wealth is less likely to coincide with weaker consumption growth in presence of a strong labor market and when household income growth is solid. Importantly, accommodative monetary policy is also found to be able to support consumption growth in difficult times.

Last but not least, Stephen Kirchner (United States Studies Centre, University of Sydney) empirically investigates "The Effect of Changes in Monetary Policy on Consumer and Business Confidence" in Australia. He finds similarities and differences when studying the determinants of these two measures of confidence. While many macroeconomic indicators are significantly correlated to both measures, changes in the official cash rate are found to impact mostly consumer sentiment, while business confidence is much less sensitive to such variations. This finding, which is interesting, clearly calls for the construction of policy models able to separate these two concepts, whose different sensitivity to the policy rate has to be understood better.

This article is protected by copyright. All rights reserved. 
These three papers cover hot topics, and they blend very nicely in this special issue. It was a pleasure to read them. I feel privileged I was in the position of managing such an exciting issue of the Policy Forum. I believe these three contributions will receive a warm welcome by academics and economists working for policy institutions in Australia and around the world.

This article is protected by copyright. All rights reserved. 


\section{University Library}

\section{- M M I N E R VA A gateway to Melbourne's research publications}

Minerva Access is the Institutional Repository of The University of Melbourne

Author/s:

Castelnuovo, E

Title:

Policy Forum: Macroeconomic Policies and the Business Cycle: Evidence and Recommendations

Date:

2020-03-01

Citation:

Castelnuovo, E. (2020). Policy Forum: Macroeconomic Policies and the Business Cycle: Evidence and Recommendations. The Australian Economic Review, 53 (1), pp.93-94. https://doi.org/10.1111/1467-8462.12363.

Persistent Link:

http://hdl.handle.net/11343/276849 